\title{
Salvaging archaeology: why cultural resource management is not part of the 'new public archaeology'
}

Richard M. Hutchings ${ }^{1, *} \&$ Marina La Salle ${ }^{2}$

The authors respond to the recent debate piece in Antiquity by González-Ruibal et al., which they claim misrepresents public archaeology by ignoring the dominant practice of cultural resource management (CRM).

Keywords: CRM, public archaeology, reactionary populism

Cultural resource management $(\mathrm{CRM})$ - defined here as commercial or salvage archaeology—is by far the most common form of public archaeology; some estimate it comprises 97 per cent of the practice (La Salle \& Hutchings 2018). It is surprising, therefore, that CRM is barely mentioned in the recent debate piece 'Against reactionary populism' (González-Ruibal et al. 2018). By ignoring CRM, the authors misrepresent public archaeology on a grand scale. We ask why and consider the implications for their 'new public archaeology'.

Feeling "politically and theoretically disempowered" by contemporary archaeology's liberal, feel-good, self-serving agenda of the status quo, González-Ruibal and colleagues imagine a new public archaeology where archaeologists: 1) "intervene in wider public debates not limited to issues of heritage or of local relevance"; 2) are "not afraid of defending [their] expert knowledge in the public arena"; and 3) are "committed to reflective, critical teaching" (2018: 507). As Zimmerman (2018) makes clear in his response, however, most North American archaeologists believe that they are already doing these things. Indeed, we know of no archaeologists who would state publicly that their research is not relevant, that they have no expertise and that their teaching is uncritical! This begs the question: who is the debate targeting? Who is its audience?

One clue lies in the authors' dense and often contradictory language, which both the public and most archaeologists would struggle to understand. For a document on the problems with public heritage and heritage experts, the reliance on post-modern jargon (e.g. 'ethical cosmopolitanism', 'enlightened subaltern', 'progressive neoliberalism', 'epistemic populism') is both problematic, in that it reduces clarity, and ironic, in that jargon alienates the public. Another clue is the absence of CRM. We conclude that the

$1 \quad$ Institute for Critical Heritage and Tourism (ICHT), 330 Spruce Avenue, Gabriola Island, British Columbia VOR IXI, Canada

2 Department of Anthropology, Vancouver Island University (VIU), Fifth Street, Nanaimo, British Columbia V9R 5S5, Canada

* Author for correspondence (Email: rmbutchings@icht.ca)

(c) Antiquity Publications Ltd, 2018 ANTIQUITY 92 365, e10 (2018): 1-3 
debate piece is written by academic archaeologists for academic archaeologists about academic archaeologists; CRM has no place in that equation (La Salle \& Hutchings 2016).

We agree with the authors' central contention-namely that community-oriented archaeology as a panacea for archaeology's ills is a self-serving whitewash, where the only needs that are consistently met are those of the archaeologists themselves (La Salle \& Hutchings 2018). We also appreciate the authors' call for critical pedagogy (Hutchings \& La Salle 2014). Our point is that while it is great-although not unproblematic - for archaeologists to argue for a politically engaged activist archaeology, it is disingenuous to do so without foregrounding CRM and archaeology's ties to the state (Hutchings \& La Salle 2017). The authors' solitary reference to commercial archaeology (González-Ruibal $e t$ al. 2018: 510) describes the situation thus:

In the commercial sector, some archaeologists wonder what will happen to CRM if neoliberal policies are applied [that] drastically undercut the requirements for conducting cultural impact assessment. The material remains of the past, along with living traditions and the environment, can often be destroyed with little or no consultation in the pursuit of ever-growing profit. Despite some arguments (e.g. Hutchings \& La Salle 2015), predatory capitalism does not need archaeologists, simply because it does not need legitimising narratives.

Here, González-Ruibal et al. correlate the weakening of heritage legislation with the loss of the archaeological record. This presumes such legislation is currently effective at protecting heritage sites, which it is not (Hutchings 2017; Hutchings \& La Salle 2017). The subtler point, however, is that CRM depends on legislation and capitalism for its existence; indeed, a threat to either could result in the loss of 97 per cent of archaeological practice.

Archaeologists are, in effect, state agents - whether employed directly by universities and museums, or as consultants doing salvage work under state permits. Modern states are inherently nationalist and capitalist. Indeed, we argue that archaeology is already neoliberal, wherein CRM proceeds as a private, for-profit enterprise, excluding the public both in process and in product (Hutchings \& La Salle 2015). An appeal for archaeologists to become political activists therefore comes up against three barriers. The first derives from archaeology being an elite-directed practice imbued with middle-class professional values; being political is not one of them. The second is that most archaeologists doing CRM are beholden to their paying clients and the state for their livelihood. In this context, being political means biting the hand that feeds. Finally, society needs to be receptive to critical views of history and heritage. Our experience is that few want to hear what are perceived to be 'negative' stories.

We hesitate to say that González-Ruibal et al. are being naïve in their call to arms, but we see a fundamental problem in their logic: they assume that archaeologists are interested in pursuing a new public archaeology, and we believe it is in their interest not to. The paradox, then, is that a new public archaeology is not achievable if it includes CRM, but excluding CRM ensures that no meaningful change will occur. Ignoring CRM altogether is not just easier for the authors, but necessary. 


\section{References}

González-Ruibal, A., P. González \& F. CriadoBOADO. 2018. Against reactionary populism: towards a new public archaeology. Antiquity 92: 507-15. https://doi.org/10.15184/aqy.2017.227

Hutchings, R.M. 2017. Maritime heritage in crisis: indigenous landscapes and global ecological breakdown. London: Routledge.

Hutchings, R.M. \& M. La Salle. 2014. Teaching anti-colonial archaeology. Archaeologies 10: 27-69. https://doi.org/10.1007/s11759-014-9250-y

- 2015. Archaeology as disaster capitalism. International Journal of Historical Archaeology 19: 699-720.

https://doi.org/10.1007/s10761-015-0308-3
- 2017. Archaeology as state heritage crime. Archaeologies 13: 66-87. https://doi.org/10.1007/s11759-017-9308-8

La Salle, M. \& R.M. Hutchings. 2016. A critical assessment of community-oriented archaeology. Canadian Journal of Archaeology 40: 164-80.

- 2018. Collaboration in colonial contexts, in A.M. Labrador \& N.A. Silberman (ed.) The Oxford handbook of public heritage: 223-37. Oxford: Oxford University Press. https://doi.org/10.1093/oxfordhb/ 9780190676315.001 .0001

Zimmerman, L. 2018. Changing archaeology's 'brand' would be helpful. Antiquity 92: 523-24. https://doi.org/10.15184/aqy.2018.16 